\title{
French environmental communication on sunflower and rapeseed oils based on life cycle assessment
}

\author{
Laureen Badey $^{1, a}$, Natie Lahitte ${ }^{1}$, Francis Flenet ${ }^{2}$ and Fabrice Bosque ${ }^{1}$ \\ 1 ITERG 11 rue Gaspard Monge, Parc Industriel Bersol 2, 33600 Pessac, France \\ ${ }^{2}$ CETIOM 11 rue de Monceau, 75378 Paris Cedex 08 France
}

Received 12 March 2013 - Accepted 2 June 2013

\begin{abstract}
The French "Grenelle" laws sparked a French national experiment trialling the environmental labelling of fast-moving consumer goods. The data required for this labelling scheme are generated by carrying out a life cycle assessment (LCA). The aim of this study is to provide all necessary information to fit the national experiment for two standard oils: sunflower oil and rapeseed oil. The complete oil life cycle was studied, from oilseed farming through to the end-of-life of the packaging. We focused heavily on the impacts of crushing and refining. The seed processing data was collected from different plants that are representative of the French crushing/refining industry and packaging site practice. The data inventory was used to calculate the identified environmental labelling indicators, i.e. greenhouse gas (GHG) emissions and water consumption. The production of $100 \mathrm{~g}$ of refined bulk sunflower and rapeseed emits 89 and $127 \mathrm{~g}$ equivalent $\mathrm{CO}_{2}$ and consumes $1.7 \mathrm{~L}$ and $0.8 \mathrm{~L}$ of water, respectively. Most impacts on the studied indicators stem from the farming phase. Energy and water consumptions during crushing and refining also weigh on the studied indicators. The results of this study provide a relevant overview of all sunflower and rapeseed oils produced in France, and are usable as standard values for vegetable oil producers and users. Oil supply chain operators can use these values to compare to their own process values and gauge the improvements brought about by their ecodesign strategies. For example, using a biomass boiler, using less packaging, and making different choices on seed suppliers can lead to a lower set of impact values.
\end{abstract}

Keywords: Rapeseed oil / sunflower oil / vegetable oil / life cycle assessment / environmental communication / greenhouse gases / water

Résumé - Détermination de l'information environnementale des huiles de colza et de tournesol produites en France par la méthode d'analyse de cycle de vie. Les lois "Grenelle » prévoyaient le déploiement d'une phase d'expérimentation d'un an permettant la mise à disposition de l'information environnementale des produits de grande consommation. La mise à disposition de ces informations environnementales a pour objectif de sensibiliser le consommateur du produit et d'inciter les producteurs à une démarche d'éco-conception. Les données nécessaires à cet affichage sont fournies par la réalisation d'analyses de cycle de vie des produits. L'objectif de la présente étude est de fournir toutes les informations utiles pour répondre aux exigences de cette expérimentation pour deux huiles : l'huile de tournesol et l'huile de colza produites en France. Le cycle de vie complet de ces huiles a été étudié, depuis la production des graines jusqu'à la fin de vie de la bouteille d'huile. Le travail s'est cependant focalisé sur les impacts de la trituration des graines et du raffinage des huiles. Les données collectées sont issues d'un panel d'entreprises (trituration, raffinage, conditionnement) représentatif de la production française d'huiles de colza et de tournesol. L'information environnementale des huiles a concerné les impacts sur les émissions de gaz à effet de serre et la consommation d'eau. La production de $100 \mathrm{~g}$ d'huile raffinée de tournesol et de colza non conditionnée émet respectivement 89 et $127 \mathrm{~g}$ équivalent $\mathrm{CO}_{2}$ et consomme respectivement 1,7 litres et 0,8 litres d'eau. La production des graines est responsable de la plupart des impacts sur ces indicateurs. La consommation d'énergie et d'eau lors de la trituration et du raffinage est également impactante. Les résultats de l'analyse de cycle de vie de ces deux types d'huiles sont applicables à l'ensemble des huiles de colza et de tournesol produites sur le territoire français, et utilisables par les producteurs et utilisateurs d'huiles végétales comme valeurs «par défaut ». Ces résultats permettront également pour un industriel de positionner son produit par rapport aux pratiques moyennes

\footnotetext{
a Correspondence: 1.badey@iterg.com
} 
nationales (référence 2010) et ainsi valoriser ses efforts d'écoconception et/ou de réduction des impacts environnementaux (utilisation de biomasse pour la production de chaleur, optimisation du poids des bouteilles plastique, etc.).

Mots clés : Huile de colza / huile de tournesol / huile végétale / analyse du cycle de vie / communication environnementale / effet de serre / eau

\section{Environmental labelling information on fast-moving consumer goods}

French "Grenelle" environmental legislation has laid down measures introducing a consumer-information environmental labelling scheme on fast-moving consumer goods. The purpose of this scheme is to raise consumer awareness, incite consumers to choose greener products, and incentivize industry producers to adopt ecodesign approaches.

The environmental information featuring on such ecolabels is calculated based on the results of product life-cycle analysis (LCA) and according to procedural rules defined by the ADEME/AFNOR platform. This platform, chartered by the French ministry for environmental affairs, is missioned with developing a common-core procedure for producing environmental labelling information. The platform is also tasked with coordinating efforts to validate a set of master guidelines (AFNOR 2011) and sector-specific guidelines (guidelines for foodstuffs, guidelines for toiletries, and so on).

In order to test the technical-economic feasibility of this scheme, a voluntary opt-in experiment was led from July 2011 to July 2012. The aim was to assess consumer perceptions and to address key issues such as accessibility for SMEs, accessibility for imports, technical feasibility, economic costs, and the data confidentiality issue. Of the 230 candidate businesses that filed an application with the ministry for environmental affairs, a shortlist of 170 were ultimately selected. Food and farming was the most represented sector (accounting for $1 / 3$ of the shortlisted businesses). The report on the conclusions of this experiment was forwarded to the French Parliament which will deliberate on whether there are appropriate grounds for mainstreaming this experimental system.

The vegetable fats subsector has asked the ITERG to partner them through this experimental scheme. The ITERG started out by proposing "baseline standard" environmental labelling information for rapeseed oil and sunflower oil (i.e. representative of French output from 2010) under the ACéVOL project (FNCG 2012; ITERG 2012) sponsored by the key trade players (Onidol, FNCG [national fats industry federation], Lesieur, Saipol, Saint Hubert). In parallel to this groundwork, the ITERG applied the same core procedure to study:

- two oils in the Lesieur range ("fleur de colza" top-quality rapeseed oil and "cœur de tournesol" top-quality sunflower oil) produced through different value streams compared to their 'baseline standard' counterpart oils;

- four margarines (salted and unsalted) listed in the Saint Hubert omega 3 product catalogue.

\section{Life-cycle assessment}

Life-cycle assessment (LCA) is a technique for quantifying the impacts of a 'product' (note that 'products' can be goods, services or processes) at each stage from resource extraction through to distribution and use and up to end-of-life disposal - an approach popularly dubbed "cradle-to-grave". LCA thus yields a fully exhaustive, multicriteria analysis of the environmental impacts of a product or process throughout its life-cycle. The LCA process is defined by standard ISO 14040:2006 and standard ISO 14044: 2006 which together specify LCA principles and framework, LCA requirements and guidelines, and guidelines on communication of the allied LCA study results.

The LCA should start by defining the functional unit, i.e. exactly what is being studied, and selecting which environmental impact categories would be appropriate to investigate. Next, once the system boundaries have been scoped, the first step consists in collecting and compiling a full inventory of the inputs (energy, chemicals, etc.) and outputs (emissions to air, soil and water, etc.) of the system studied. This is the data (called the life-cycle inventory, or LCI) that will subsequently be converted into impact values using characterization factors. In practice, the vital or indirect input flows enter the system in determined quantities. It is possible to account these in the product impact studied after performing three operations:

- the quantity of input or emission is related to the functional unit of the product studied,

- these physical flows are then converted into environmental impacts using characterization factors geared specifically to the environmental indicators being monitored (nonrenewable energy consumption, greenhouse gas (GHG) emissions, toxicity, and so on $)^{1}$,

- the full set of impacts for each input and output is summed for the environmental indicators monitored so as to propose an aggregate value at the desired level of analysis, i.e. over the full life-cycle, at a substage, etc.).

The LCA is generally run on dedicated software $\left(\right.$ Simapro $^{\circledR}$, Gabi, among others) that will feature:

- an input matrix for LCIs compiled in business settings,

- LCI databases (where all the inputs and outputs for plastics production, for instance, can be found),

- calculation procedures featuring all the characterization factors needed.

\section{Objectives of the ACéVOL project}

The ACéVOL project was set up by the key players in the vegetable fats subsector with the aim of building a set of baseline reference values for vegetable oils. The primary objective of the project was to calculate the environmental impacts of baseline-standard oils, which in this case were rapeseed and

1 The characterization factors serve to convert input data (e.g. using $5 \mathrm{~kg}$ of fuel oil) into impact values (using $5 \mathrm{~kg}$ of fuel oil releases $2 \mathrm{~kg}$ of equivalent $\mathrm{CO}_{2}$ and consumes $1 \mathrm{~L}$ of water). 
sunflower oils, representative of French output from 2010, so that this data could be made available to oil producers and users alike. The intended audiences for the results of this study are:

- Industry businesses looking to position their products against average national production channels (2010 as benchmark) and thus draw added value from their ecodesign and/or environmental impact reduction efforts (biomass boiler used as heating system, optimized weight of plastic bottles, etc.); for example, these results have been used to assess the environmental benefits of ecodesign initiatives set up by Lesieur for their "fleur de colza" and "cœur de tournesol" product lines,

- Vegetable oil users, essentially the other client sectors: food manufacturer industries (margarines, biscuits, readymade meals), restaurant and catering industries (fast-food chains, etc.) and non-food industries (glycerol derivatives, esters, lubricants, etc.) looking to assess the impacts of their own products; for example, this data has been used to assess the environmental impacts of Saint Hubert brand margarines (which count oil among their ingredients).

\section{Methodology options chosen under the ACéVOL project}

The ADEME/AFNOR platform tasked with setting a common-core environmental information calculation scheme for product labelling has validated two reference guides:

- a general reference guide setting out general principles for ecolabelling (AFNOR 2011),

- a specific reference guide for foods and animal feeds (AFNOR 2012).

The key methodology decisions were taken by the members of the project steering committee (cited in the acknowledgements section) and are fully consistent with the recommendations of these reference guides.

\subsection{Functional unit studied}

In LCA, the functional unit defines what system precisely is being studied, providing a reference to which the consumptions and emissions can be related. The product's environmental impacts have to be related to the product's function, particularly as a basis for cross-comparing two products from the same category (for example, the functional unit of a paint system should be "paint protecting a $1 \mathrm{~m}^{2}$ unit surface" and not "100 mL of paint").

The function unit defined for vegetable oils is a unit mass, set as $10 \mathrm{~g}$ of oil as consumed in mass retail channels". The results are also reported for $100 \mathrm{~g}$ of oil as consumed in mass retail channels and $100 \mathrm{~g}$ of bulk refined edible oils. This functional unit accounts for material losses during the refined oil production process (crushing and refining), the packaging process, and distribution (warehousing losses, etc.). The oil is considered along with its packaging system (bottle, boxing, etc.), which varies in composition according to oil end-use. The goal is to make these values available to vegetable oil processors and user businesses. These functional units have to be used when reporting the environmental information to stakeholders (consumers or oil user businesses). However, relating environmental impacts to product unit mass makes it difficult to run comparisons between different foods or different diets (such as vegetarian or organic). Studies are underway to improve on this functional unit, including by integrating nutritional dimensions. Several studies are based on NRF9.3 - the "nutrient rich foods index" 9.3 , which combines 9 nutrients to encourage in diet and 3 nutrients to limit in diet. This index is calculated based on the number of nutrients contained in $100 \mathrm{~g}$ of product serving divided by their recommended daily allowances. This approach represents a first step towards a better-integrated understanding of food product functionality, but no study to date has integrated the hedonic factor inherent to eating.

\subsection{Scope of the study}

LCA analyzes the full end-to-end product lifecycle, from raw materials manufacture through to the end-of-life of the finished product, via the market sale phase and the product use phase. Here, the scope boundaries extend right from seed production through to the end-of-life of the oil packagings. This scope is depicted in detail in Figure 1. However, the study focused heavily on the oil production processes. We drew up a detailed inventory of the production-phase (crushing and refining) flows and impacts.

The warehousing and in-store sales phases were excluded from the scope of the study, for several reasons - primarily because the impacts were considered negligible, but also because the data shows very strong geographic variability, as well as proving a real struggle to collect. For these same reasons, we also elected not to assess warehouse-warehouse and warehouse-retail store transport. Note that the information on point-of-sale-consumer home transport has already been taken outside the scope boundaries of environmental labelling (AFNOR 2011), and was not therefore included in this study.

Both rapeseed oil and sunflower oil can be used in seasonings or for shallow-frying and deep-frying. The impact of use in seasonings is practically zero. The impacts tied to cooking and frying (electricity consumption by hotplates or deep fat fryers, etc.) are not readily assessable. One of the main challenges is to determine a set of rules for partitioning impacts between products. For example, when cooking chips, should the impacts tied to deep fat fryer consumption be allocated to the "potato" product or to the "oil" product? End-consumers buying cooking oil do not intend to eat it as such but to cook the product with it. The use phase was therefore not integrated in the study program. For these same reasons, we also elected not to assess the oil product end-of-life phase (pending a ruling on how to partition impacts between products for cooking or frying).

\subsection{Allocation method used to partition impacts between oils and oil co-products}

When performing LCA on a product, it can sometimes prove necessary to define allocation rules for partitioning between system-output co-products. There are various allocation methods available, all of which heavily influence the LCA 


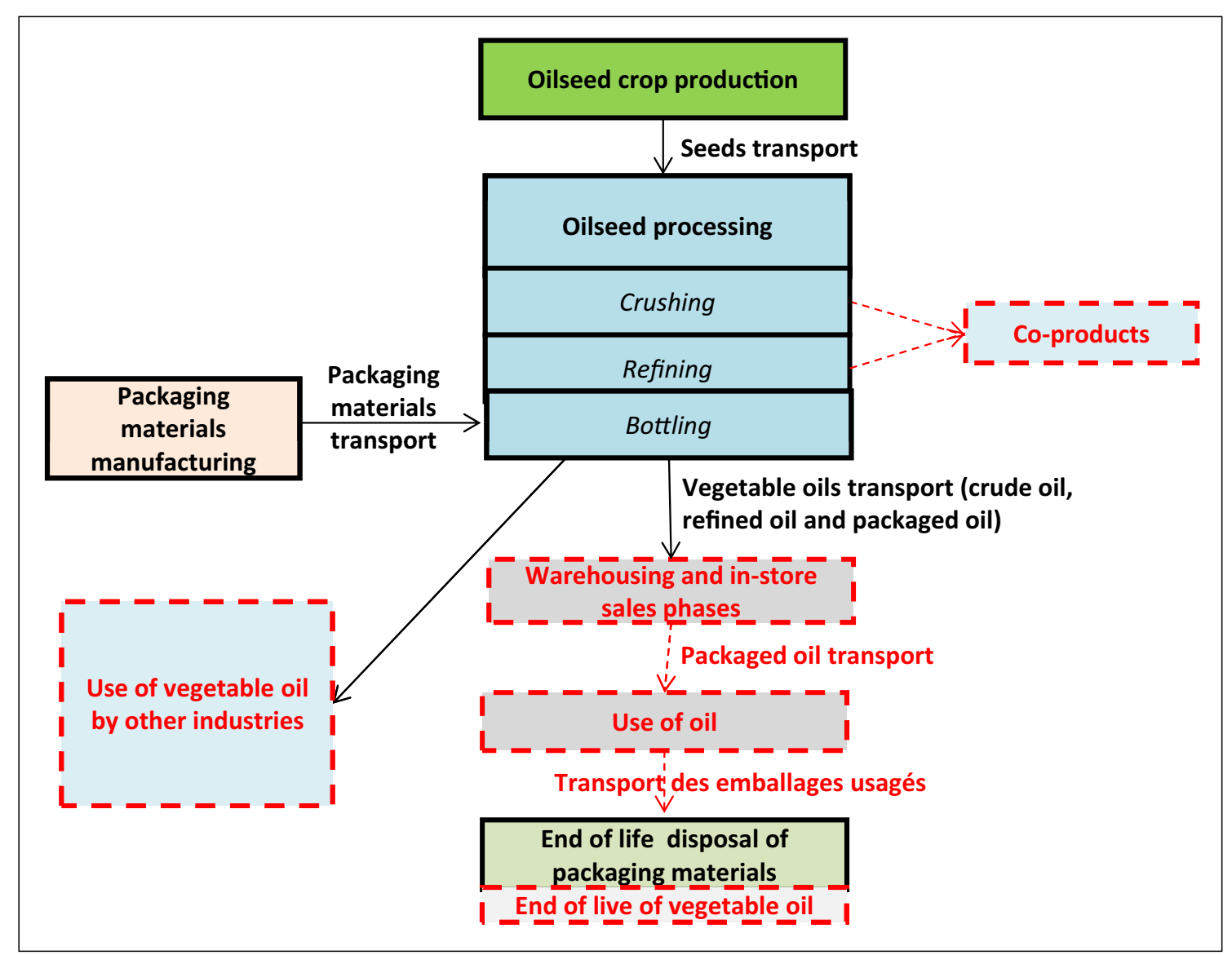

Fig. 1. Scope of the study for the implementation of the life cycle assessment of sunflower and rapeseed oils. The cells in red dotted line are the steps excluded from the study. An energetic allocation has been done to the co-products (the use and the end of life of co-products are excluded from the study).

results. The allocation procedure has to be chosen according to the aim of the study and the fate and functionality of the different co-products. Choosing the right allocation method often presents considerable challenges, as it is difficult to identify common-denominator characteristics spanning the various different co-products.

The oil extraction process generates an array of recoverable co-products, making it necessary to partition the environmental impacts between the "oil" product and its coproducts. The vegetable fats subsector has opted to allocate burden according to product and co-product energy content based on Net Calorific Value (NCV; see Tab. 1), using the following equation:

$$
A F i=N C V i \times Q i / \Sigma(N C V i \times Q i)
$$

$A F i$ : allocation factor for product " $i$ "

$N C V i$ : net calorific value of product " $i$ "

Qi : quantity of product " $i$ ", in kilograms

Example calculation: in the crushing subprocess, one tonne of sunflower seeds is able to produce $490 \mathrm{~kg}$ of sunflower meal $(\mathrm{NCV}=17.14 \mathrm{MJ} / \mathrm{kg})$ and $440 \mathrm{~kg}$ of crude sunflower oil $(\mathrm{NCV}=36.00 \mathrm{MJ} / \mathrm{kg})$; the impact burden of the farming and crushing (pressing and extraction) phases will be partitioned $65 \%$ to crude oil, based on the following equation: $(440 \times 36) /(440 \times 36+490 \times 17.14) \times 100$.
Table 1. Low heating values (LHV) for energetic allocation purpose between oilseeds, vegetable oils and co-products (MJ / kg of dry matter) - (ADEME, 2010).

\begin{tabular}{lc}
\hline & LHV \\
\hline Vegetable oils & 36 \\
Meal cake & 17.14 \\
Acid rich oil & 36 \\
Desodorisation condensates & 36 \\
\hline
\end{tabular}

In contrast with other allocation models not linked to a physical criterion, such as economic-value partitioning, a physical criterion-linked allocation model such as energyvalue allocation is the only solution able to guarantee stable and robust environmental profiles of vegetable oil production sectors. The fluctuating market prices and stiff challenges involved in determining market values for certain intermediates and co-products for which there are no organized markets effectively rules out the economic-value partitioning approach.

In the case of vegetable oil biofuels, the ADEME study finalized in February 2010 on LCAs applied to first-generation biofuels used in France also recommended using energy-value partitioning to allocate between the oil and its co-products (ADEME 2008). The LCA procedures for this study were selected following nationally-led dialog and discussion between 
experts from the various biofuel value chains, and are therefore nationally recognized. The energy-value allocation principle was also adopted under the common framework of the EU directive on renewable energies (directive 2009/28/EC of the European Parliament and of the Council of 23 April 2009 on the promotion of the use of energy from renewable sources).

The co-products integrated for 'baseline standard' rapeseed oil and sunflower oil are de-oiled meal cakes (derived by crushing the seeds to produce crude oil) and two refiningprocess co-products: the acid-rich oils (produced when processing the neutralization pastes via a process called "breaking" the paste) and the deodorizing-process condensates (chemical refinement).

These meal cakes generally net value via the animal feed market. The impacts are allocated between the meal cake and the crude oil. They are farming-phase impacts (producing oilseed crops), seed transport impacts, and crushing-process impacts (energy consumption, water consumption, etc.). Any variation in yield between the crude oil and the meal cake, like any variation in NCV, can have a tangible (non-negligible) effect on the result of the LCA.

The impacts allocated to refined oil and refining-process co-products are farming-phase impacts, seed transport impacts, crushing-process impacts, crude oil transport impacts, and refining-process impacts (energy consumption, joint process input consumptions, etc.). The impacts of the paste "breaking" process also have to be partitioned between the refined oil and its co-products, as there was no way to separate the individual paste-breaking process consumptions (energy, inputs) from the wider refining-process consumptions.

Note that vegetable oil production can also generate other co-products, depending on the processes implemented. For example, physical-mechanical oil refining processes generate gums or fatty acid distillates.

\subsection{Data collection procedure}

All of the data tied to the form and quantity of the inputs (raw materials, chemicals, energy, etc.), the outputs, and the emissions to air, soil and water throughout the vegetable oil life-cycle has to be collected. The reliability of the environmental information given to stakeholders hinges on quality data collection. However, data collection can prove a long and tedious task.

The data were collected for the purpose of providing results applicable to all rapeseed and sunflower oils produced in mainland France. This data and the procedures used to integrate the impacts of farming rapeseed and sunflower seed crops were essentially borrowed from the ADEME's biofuel study (ADEME 2010). The CETIOM (French technical center for oilseed crops and industrial hemp) lent support to the project steering committee and the ITERG on interpreting this data, and completed the LCIs where necessary. Concerning industrial oil production, all the data was collected based on 2006-2010 figures for edible oil production plants run by Saipol and Lesieur. The project steering committee deemed that this panel of industrial-scale plants was representative of French sector as a whole. This industrial data made it possible to integrate the mean consumptions and emissions figures recorded in France over the 2006-2010 period. The oils modelled do not, therefore, correspond to real-world brand oils on sale, but instead give a generic picture of sector practices in 2010.

The "1L" PET bottle format represents the majority of rapeseed and sunflower oil sales in France, and was consequently the only packaging system assessed.

The packaging end-of-life scenarios used were drawn based on our hypotheses and published papers (ADEME 2009; ADEME 2010; RDC Environnement 2010; Shen 2011) and completed by following the recommendations given in the "methodology for assessing the environmental impacts of foods" master guideline validated by the ADEME/AFNOR platform (AFNOR 2012).

\subsection{Options chosen for the environmental indicators considered}

Environmental indicators can be used to assess a multitude of environmental impacts (effects on climate change, effects on ozone layer depletion, etc.). For each environmental impact, there are several calculation procedures able to translate the information collected during the LCI into impacts on the environment. Some indicators can be aggregated in order to calculate a more global impact (for example, eutrophication and climate change indicators can be aggregated to calculate a more global indicator on the threat to biodiversity).

Impact selection should aim for the most relevant and significant environmental impacts generated by the product. The ADEME/AFNOR platform recommends limiting consumer information to just three criteria. The indicators considered as most relevant for foods are: climate change (GHG emissions), water quality (aggregating the water consumption, eutrophication and aquatic ecotoxicity indicators), and "biodiversity", for which a core assessment method has yet to be defined (AFNOR 2012).

The project steering committee's aim is to propose oil environmental labelling information based solely on indicators built from the most robust calculation procedures, i.e. GHG emissions (or impact on climate change) and water consumption.

The other indicators proposed for foods by WG 1 "human food products and pet foods" were ruled out for vegetable oils following the experimental trial scheme, as - in contrast to the water consumption and climate change indicators - they were unable to yield robust results due to under-developed calculation methods (ecotoxicity and biodiversity) and the lack of fit between the data collectable and the data needed for reliable calculation (eutrophication).

\section{Climate change}

Much of the thermal radiation emitted by the Sun gets reflected by the Earth back into the atmosphere, where it holds the average temperature on Earth at $15{ }^{\circ} \mathrm{C}$. This natural phenomenon is called the greenhouse effect. Anthropogenic activity increases the concentration of greenhouse gases (such as $\mathrm{CO}_{2}$ ) in the atmosphere, which progressively "traps" more 
and more radiation that gets re-radiated back to the Earth's surface and "warms" the average surface temperature. This phenomenon is called climate change. Climate change can be assessed based on the amount of GHGs emitted in the atmosphere. The baseline reference unit is $\mathrm{CO}_{2}$ : all GHG measurements can be ratioed to a functionally equivalent amount of $\mathrm{CO}_{2}$. This calculation method, proposed by the international panel on climate change (IPCC), has become the international consensus procedure. To illustrate, each meal eaten in France generates an average $3 \mathrm{~kg}$ of equivalent $\mathrm{CO}_{2}$ emissions (CGDD [Department of the Commissioner-General for Sustainable Development] 2011).

Note that land-use and (direct and indirect) land-use change in farming are strong drivers of GHG emissions and therefore climate change. This is because soils stock carbon as organic matter. Soils are effectively the world's third biggest carbon sink. When the soil organic matter becomes exposed to atmospheric oxygen, the carbon it contains binds to this atmospheric oxygen, forming $\mathrm{CO}_{2}$. This essentially natural phenomenon can be speeded up by anthropogenic activities, particularly certain farming practices. Modification of in-soil carbon stocks is rarely assessed when calculating the impacts of farmed products, yet farming is responsible for an estimated $15 \%$ of GHG emissions worldwide, and integrating land-use and land-use change would drive this figure up to $30 \%$. Consequently, the amount of GHGs emitted in the production of a food product as calculated to date could well be revised upward (the impact can be doubled). However, despite a flurry of studies attempting to assess land-use and direct and indirect land-use change, no consensus method has emerged. Land-use change could turn out to be a significant factor for the vegetable fats subsector.

\section{Water consumption}

Throughout the life-cycle of a product and its packaging (raw material acquisition, manufacturing, transport, use, endof-life), water gets used for an array of functions (irrigation, cleaning, cooling, etc.). This water consumption can ultimately drain the available water resource reserves. The "water consumption" indicator is designed to assess water consumption at every stage in the product life-cycle (from farming to input production, packaging production, etc.) by accounting for both direct consumption (tapping mains water, well drilling) and indirect consumption (water consumption to manufacture production-process inputs).

This indicator is calculated by taking raw consumption figures and subtracting the volume of:

- discharges into the same reservoir as where the water was originally tapped,

- water catchment from stable water tables,

- water catchment from the sea.

For example, cooling water taken from a lake, channelled through heat exchangers, and re-charged without phasechange (only thermal change) back into the same lake, does not get accounted. Similarly, centrifuge water is not accounted for.
For direct water consumption, and particularly field irrigation, the vegetable fats subsector recommends only accounting utility water (which means rainwater "consumption" is not assessed). The "vegetable oils" sector also considers that no water taken from a stable water table, chiefly because France has no set definition and no detailed maps of its stable water tables.

LCAs rarely integrate the water consumption indicator. Data on water consumption in the processes transforming oilseed into oil is easy to collect (direct consumption), whereas water consumption tied to manufacturing production-process inputs (indirect consumption) is far more difficult to identify and so has to be adapted from databases. This indicator is very tricky to interpret.

Note too that it reflects water use in its quantitative dimension but fails to capture the qualitative dimensions of local conditions and water stress. To illustrate, a French citizen consumes an estimated $151 \mathrm{~L}$ of water per day in the course of their everyday activities, as showering, flushing the toilet, washing up, the washing machine, drinking, and cooking all take their toll (CGDD [Department of the CommissionerGeneral for Sustainable Development] 2011).

\section{Results: environment impact assessment per life-cycle stage}

\subsection{Oilseed crop production}

The impacts on climate change at this stage are primarily driven by dinitrogen monoxide emissions when spreading nitrogen fertilizers (Fig. 2), which account for 44\%-54\% of total GHG emissions generated by oilseed crop production. Manufacturing mineral nitrogen fertilizer accounts for $27 \%-37 \%$ of GHG emissions. Mechanization (i.e., diesel consumption by farm machinery) also accounts for a significant share $(9 \%-19 \%)$ of total GHG emissions.

"Water consumption" is primarily impacted by cropfield irrigation (see the case of sunflowers; Fig. 3), fertilizer production $\left(\mathrm{P}_{2} \mathrm{O}_{5}\right.$, etc. $)$, and seed-drying.

Note that plot yield (quality of oilseed produced per hectare) is a key parameter for relating consumption levels (fertilization, etc.) and emissions to a functional unit.

Efforts to curb the impact of oilseed production will need to focus on limiting the amount of fertilizer inputs - particularly nitrogen fertilizer - applied on-field. Irrigation is also a significant lever of action for limiting the impacts on the water resource. As rapeseed is not irrigated in French practice, it has a lower impact on the "water consumption" indicator than sunflower crops. However, fertilizer consumption and irrigation water cannot be reduced at the expense of plot yield.

An ADEME-funded project (called Agri-BALYSE) is currently underway to revise the environmental impact assessment of French farmed crops One of the project deliverables is to propose a mean French value for rapeseed and sunflower seed. Note that Agri-BALYSE is not set to propose a method for integrating land-use change. 


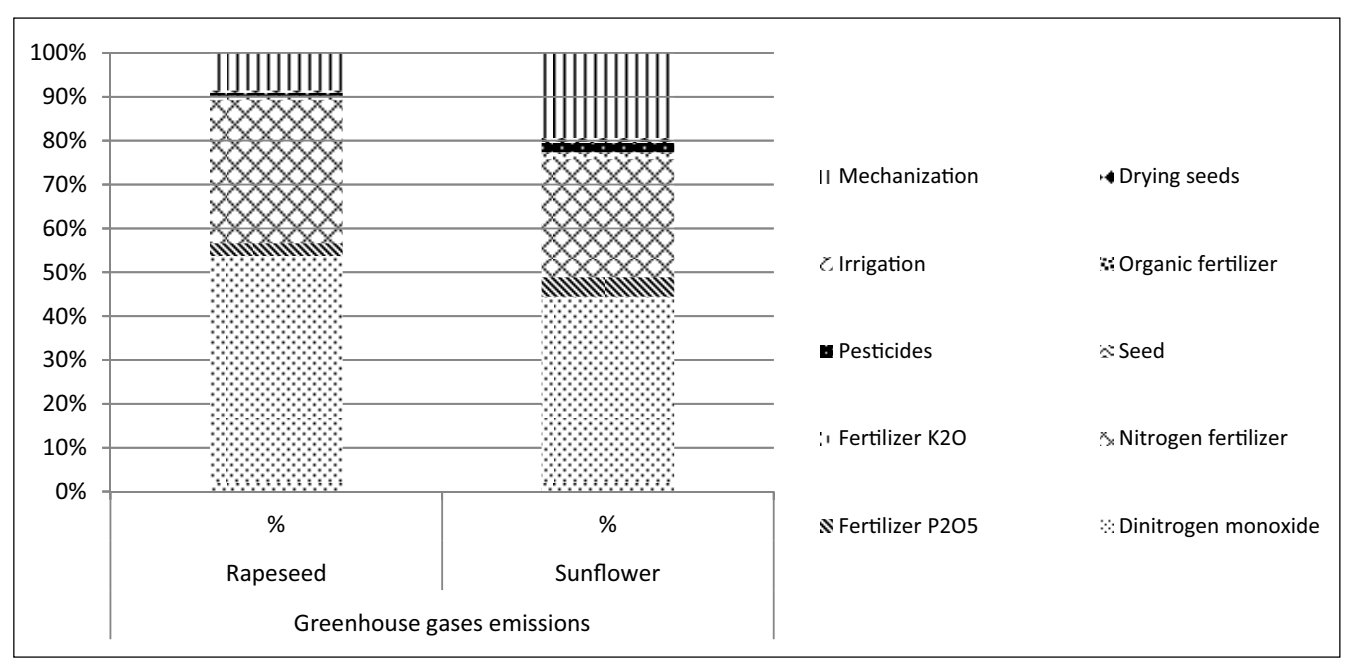

Fig. 2. Breakdown of greenhouse gases emissions occuring during rapeseed and sunflower seed crop production (\%).

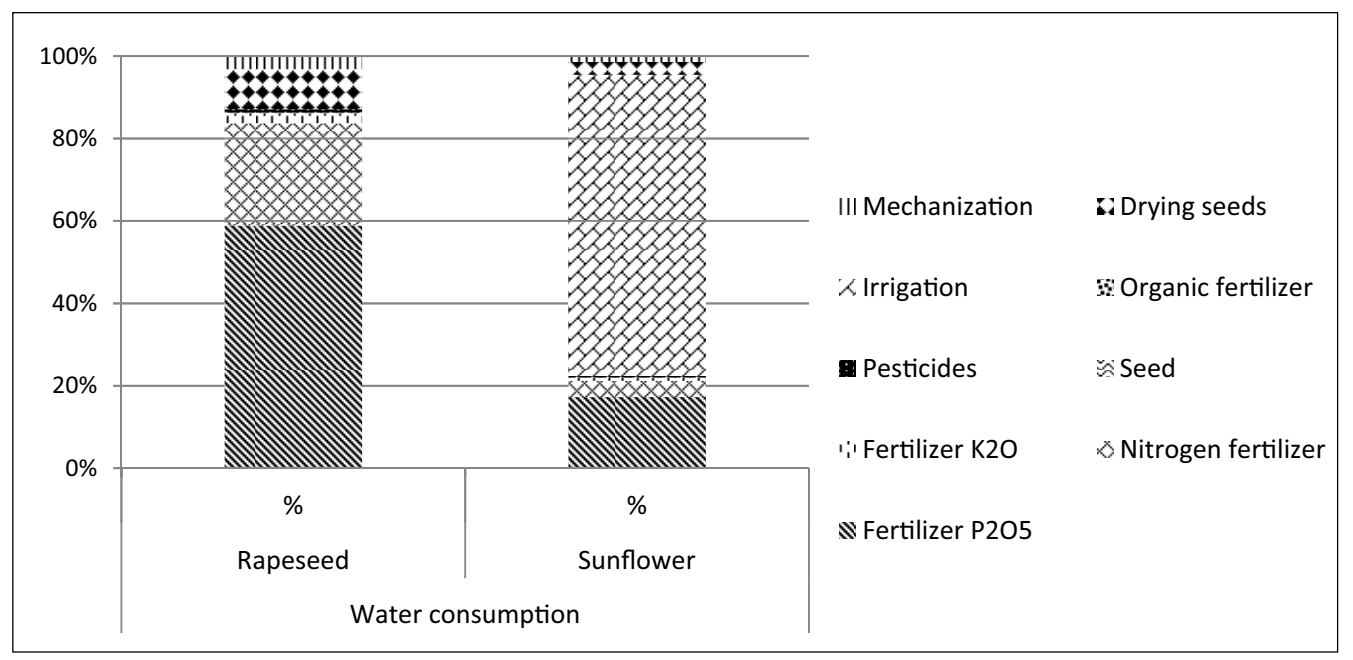

Fig. 3. Breakdown of water consumption occuring during rapeseed and sunflower seed crop production (\%).

\subsection{Oilseed processing}

The term "oilseed processing" spans the crushing, refining and bottling (excluding packaging material manufacturing) stages.

The crushing and refining stages account for the vast majority of GHG emissions generated, with bottling accounting for just 5\%-6\%. These GHG emissions are primarily driven by pressurized-steam generation and electricity consumption. Direct in-plant water consumption accounts for the majority of total water consumption, although indirect water consumption tied to crushing and refining production-process inputs (water used to produce electricity, natural gas, chemical agents, etc.) accounts for a non-negligible share (Fig. 4).

For the 'baseline standard' oils, the model worked to the assumption that the pressurized steam was produced from natural gas. However, the oils sector also uses two other combustibles for producing pressurized steam:

- wood shavings,

- sunflower seed hulls (derived from sunflower seed husking).
Using natural resources should have a beneficial effect on GHG emissions (emissions cut by $95 \%$ if using wood shavings and cut by $66 \%$ if using seed hulls), while using wood shavings should also cut water consumption by $53 \%$. Using a biomass boiler system would therefore mitigate the impacts on both climate change and water consumption, but the impacts on the other environmental indicators have not been assessed.

\subsection{Packaging materials}

The environmental impacts driven by packaging materials cover packaging material manufacturing (PET bottles, carton, etc.) and their end-of-life disposal (recycling, incineration, landfill). Packaging material manufacturing accounts for the brunt of the impacts on climate change and water consumption. PET bottle manufacturing accounts for around $80 \%$ of GHG emissions and $80 \%-90 \%$ of water consumption (Fig. 5). Note that recycling packaging materials avoids the burden of natural resource consumption (producing virgin material), in which case "avoided emissions" are modelled, where the aim 


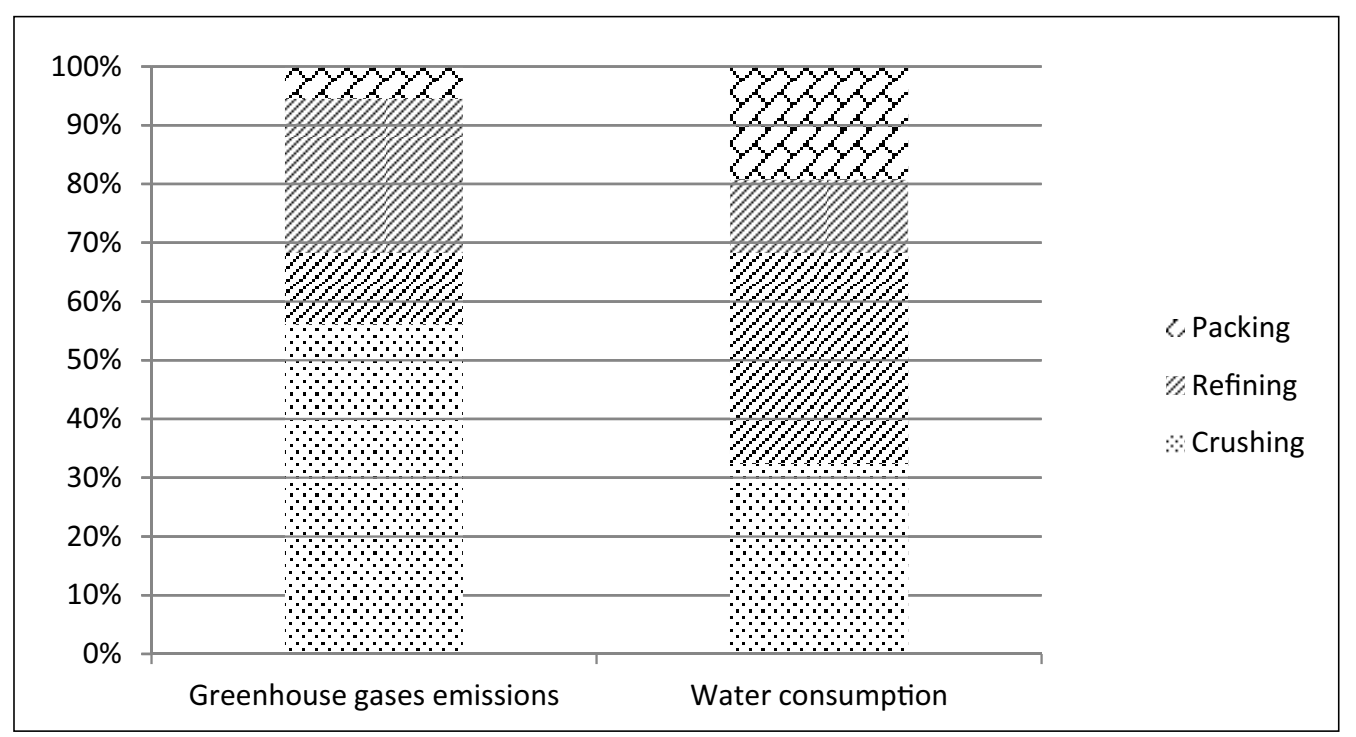

Fig. 4. Breakdown of greenhouse gases emissions and water consumption occuring during rapeseed and rapeseed oil processing (\%).

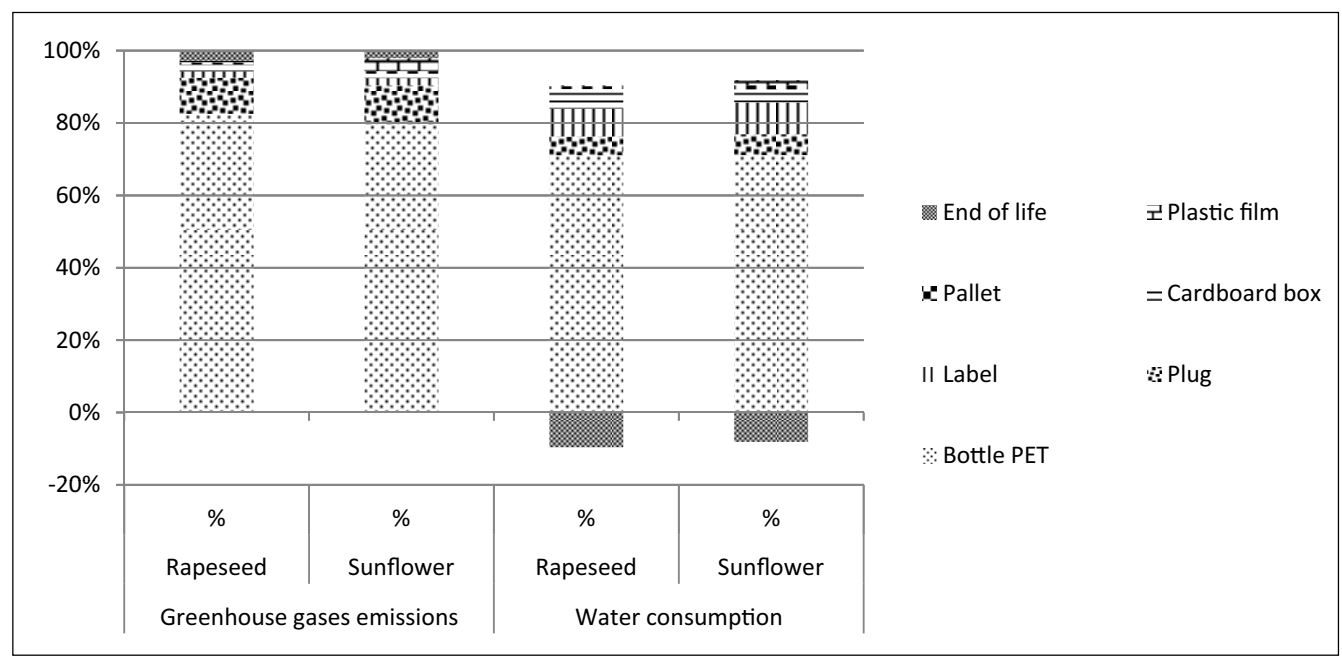

Fig. 5. Breakdown of greenhouse gases emissions and water consumption occuring during the manufacturing and the end of life disposal of rapeseed oil and sunflower oil packaging materials (\%). The environmental impacts below the abscissa axis are the impact avoided during the recycling.

is to calculate the environmental benefits brought about by recycling. These benefits are significant for water consumption.

\subsection{Transport}

We considered the transport of both oilseeds and oils (crude, refined and bottled) throughout the life-cycle, plus the transport of joint process inputs (bleaching earth, etc.) and the transport of packaging materials. Transporting bottled oil to the "client" warehouse accounts for the majority of GHG emissions (Fig. 6). This result is mainly explained by the fact that bottled oil is trucked over longer distances than bulk refined oil. The fact that bottles weigh less and that bottle haulage trucks operate at lower fill rates than for bulk tanker haulage also explains this difference. Oilseed also gets transported by long-distance road haulage, but container shipping remains the

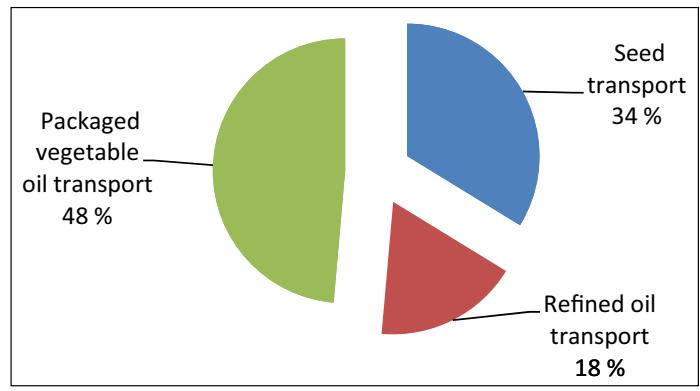

Fig. 6. Breakdown of greenhouse gases emissions for transport.

main mode of transport employed, which reduces the GHG impact of oilseed transport. The transport of production factor inputs (hexane and other chemicals, etc.) accounts for less than $0.5 \%$ of impacts. 


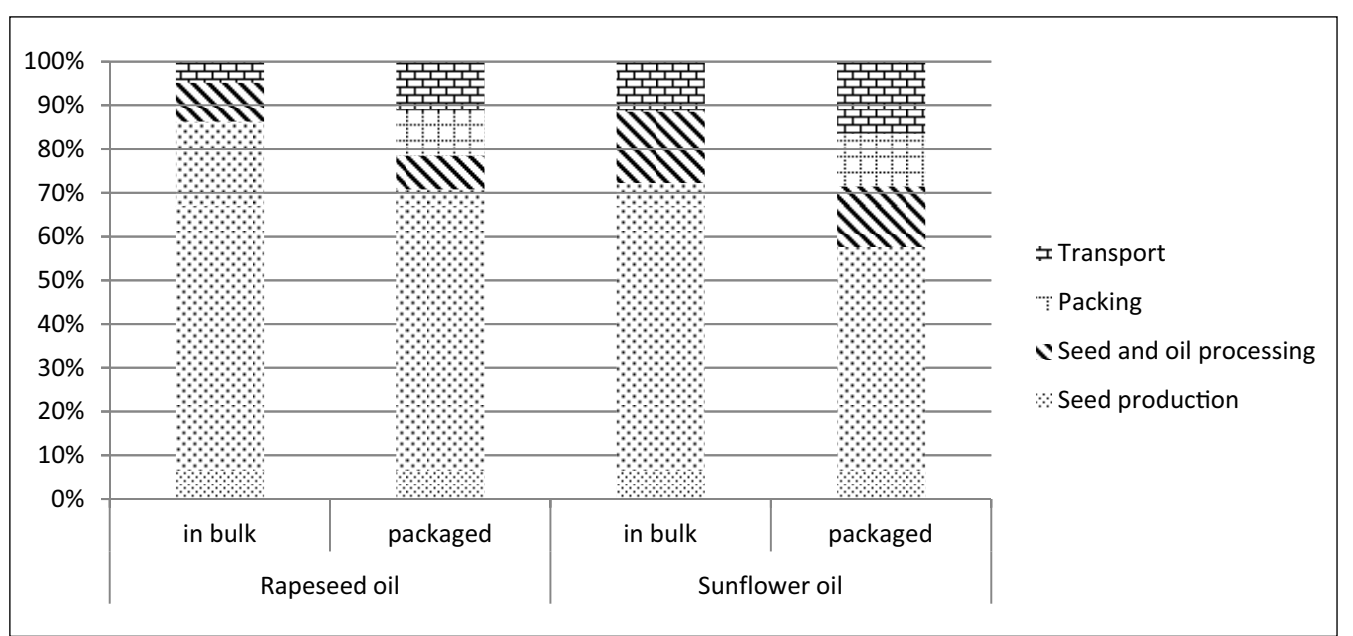

Fig. 7. Breakdown of greenhouse gases emissons occuring during the entire life cycle of refined rapeseed and sunflower oils (\%).

Table 2. Amount of greenhouse gases emissions and water consumption occurring during the production of $100 \mathrm{~g}$ of bulk rapeseed refined oil and packaged rapeseed refined oil.

\begin{tabular}{|c|c|c|}
\hline & Bulk vegetable oil refined & Packaged vegetable oil refined \\
\hline Emissions of greenhouse gases ( $\mathrm{g} \mathrm{CO}_{2}$ eq.) & 127 & 154 \\
\hline $\begin{array}{ll}\text { Total consumption } \\
\end{array}$ & 0.7 & 1.0 \\
\hline $\begin{array}{l}\text { Including crop field irrigation and } \\
\text { process water }\end{array}$ & 0.1 & 0.1 \\
\hline $\begin{array}{l}\text { Including water used for inputs } \\
\text { production }\end{array}$ & 0.6 & 0.9 \\
\hline
\end{tabular}

Table 3. Amount of greenhouse gases emissions and water consumption occurring during the production of $100 \mathrm{~g}$ of bulk sunflower refined oil and packaged sunflower refined oil.

\begin{tabular}{|c|c|c|c|}
\hline & & Bulk vegetable oil refined & Packaged vegetable oil refined \\
\hline \multicolumn{2}{|c|}{ Emissions of greenhouse gases ( $\mathrm{g} \mathrm{CO}_{2}$ eq.) } & 89 & 112 \\
\hline \multirow{3}{*}{ Water consumption (liter) } & Total consumption & 1.7 & 1.9 \\
\hline & $\begin{array}{l}\text { Including crop field irrigation and } \\
\text { process water }\end{array}$ & 1.1 & 1.1 \\
\hline & $\begin{array}{c}\text { Including water used for inputs } \\
\text { production }\end{array}$ & 0.6 & 0.8 \\
\hline
\end{tabular}

\section{Results: environment impact assessment of the entire life-cycle}

\subsection{Climate change}

The results of the climate change impact assessment for "baseline standard" rapeseed oil and sunflower oil are detailed in Tables 2 and 3. The results are reported for oils at the "refinery plant gate", i.e. ready to go to vegetable oil processors (bulk refined edible oils), and bottled oils ready for the endconsumer (packaged refined oils).

The GHG emissions are primarily driven by oilseed crop production (71\% and 58\% for rapeseed oil and sunflower oil, respectively), chiefly due to dinitrogen monoxide emissions when spreading nitrogen fertilizers (Fig. 7).

Transport of the oilseed and then the oil throughout its lifecycle accounts for $12 \%-15 \%$ of GHG emissions. The manufacturing and end-of-life disposal of the materials used to package and bottle the oil represent $10 \%-12 \%$ of the impact on GHG emissions, which are primarily driven by bottle manufacturing. The packaging recycling stage can significantly cut the total GHG impact of the oil product.

The processes transforming oilseed into oil account for $8 \%-14 \%$ of GHG emissions. The crushing stage accounts for the majority of this impact category, followed by the refining stage. The majority of GHG emissions from these processing stages are due to the energy consumption involved.

\subsection{Water consumption}

The results of the water consumption impact assessment for 'baseline standard' rapeseed oil and sunflower oil are detailed in Tables 2 and 3. The results are reported for oils at the "refinery plant gate", i.e. ready to go to vegetable oil processors (bulk refined edible oils), and bottled oils ready for the end-consumer (packaged refined oils).

The "water consumption indicator" aggregates water consumption in the processes transforming oilseed into oil (direct 


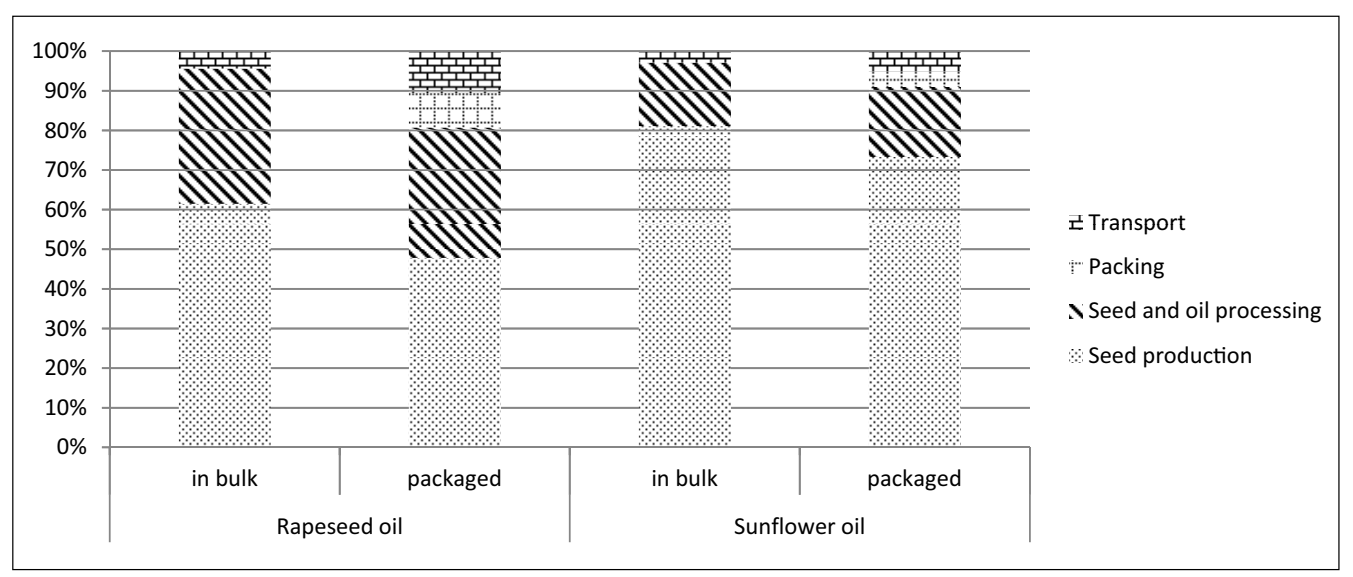

Fig. 8. breakdown of water consumption occuring during the entire life cycle of refined rapeseed and sunflower oils (\%).

consumption, including as pressurized steam) along with water used to manufacture production-process inputs (chemical inputs, packaging materials, etc.) and water used to produce electricity and natural gas.

Water consumption profile is heavily dependent on crop irrigation. The crop farming phase is the heaviest water-user (47\% for rapeseed oil and up to $73 \%$ for sunflower oil; Fig. 8). The water used stems from both direct consumption, to irrigate the sunflower crop, and indirect consumption, largely for $\mathrm{P}_{2} \mathrm{O}_{5}$ fertilizer manufacturing, chiefly for rapeseed. The processes transforming oilseed into oil account for $18 \%-33 \%$ of total water consumption. Transport of the oilseed and then the oil throughout its life-cycle accounts for 5\%-10\% of total water consumption. Packaging material manufacturing accounts for $4 \%-10 \%$ of water consumption.

\subsection{Lessons learned}

The two oils studied (rapeseed and sunflower) show a position differential on the two environmental impact indicators studied. The GHG emissions calculated for each stage in the life-cycle reflect different patterns of energy use, input use (amount of fertilizer, packaging weights, etc.) or transport between the two oil products. A significant fraction of this difference is related to the fact that sunflower seed crops require less fertilizer input.

The difference in water consumption is explained entirely by the fact that $2 \%-3 \%$ of sunflower cropfields are irrigated whereas rapeseed plots are never irrigated. Note that sunflower crops require comparatively far less water than other crops like corn.

\section{Perspectives}

The aim of this study was to produce the key information for introducing environmental labelling information for "baseline standard" rapeseed oil and sunflower oil, within the framework of a national-scale experimental trial scheme chartered by the French ministry for environmental affairs from 2011. The life-cycle analysis on these two model oils has provided results applicable to all rapeseed and sunflower oils produced in mainland France and that all vegetable oil producers and users can readily use as "default" values. Lesieur led this life-cycle analysis on two oil products (branded "fleur de colza" and "cœur de tournesol"), and compared its process results against the "baseline standard" values for rapeseed oil and sunflower oil. This comparison enabled Lesieur to evaluate the benefits of its eco-design strategy and highlight areas where further improvements could be made. Saint Hubert used the proposed "default" rapeseed and sunflower oil values to calculate the environmental impact of its "Saint Hubert omega 3" brand margarines.

Based on the experience gained and lessons learned during this experimental trial, the ITERG has engaged in the process of drafting sector-specific methodology reference guide for assessing the environmental impacts of vegetable oils. The aim of this guide is to set sector-specific procedural rules to be used when providing environmental labelling information on vegetable oils. Any company looking to provide environmental labelling information on vegetable oils will need to work to this reference guide document.

In 2012, alongside this research work, the ITERG has also developed a simplified method for assessing the environmental impacts of the entire vegetable oil industry product range. This simplified method substantially reduces the data collection effort by proposing default values for certain data items that are not readily accessible or that have little impact on the LCA results, and by proposing a list of data that can be excluded from scope of the study.

At European level, the EC is currently finalizing a protocol designed to propose a multicriteria environmental impact assessment method for foods through inter-company coordination and dialog with consumers. The EC also plans to release versions of this protocol for different product categories, and to publish the allied databases and impact calculation tools.

Acknowledgements. The authors thank the ONIDOL and the GTOM for funding support. The authors also thank the project steering committee members who contributed to this study: Mireille BessonGiordano (St Hubert), Hubert Bocquelet (FNCG), Jean-Marc Buteux (Lesieur), Julien Coignac (Sofiprotéol), Sylvie Dauguet (CETIOM), Pauline Robert (FNCG), Bernard Ticot (ONIDOL) and Sylvain Tostain (Saipol). 


\section{References}

ADEME, MEDAD, MAP, ONIGC, IFP. 2008. Élaboration d'un référentiel méthodologique pour la réalisation d'Analyses de Cycle de Vie appliquées aux biocarburants de première génération en France. Rapport 2008, 130 p.

ADEME. 2009. Le recyclage en France annuel - données 2008. Rapport 2009, 16 p.

ADEME, Ministère de l'écologie, de l'énergie, du développement durable et de la mer, Ministère de l'alimentation, de l'agriculture et de la pêche, France Agrimer. 2010. Analyses de cycle de vie appliquées aux biocarburants de première génération consommés en France. Rapport 2010, 236 p.

ADEME. 2010. Bilan du recyclage 1999-2008. Matériaux et recyclage - Données détaillées par filière - Partie 1. Rapport 2010, $178 \mathrm{p}$.

AFNOR. 2011. BPX 30-323-0 - Principes généraux pour l'affichage environnemental des produits de grande consommation - Partie 0 : principes généraux et cadre méthodologique. Référentiel 2011.
AFNOR. 2012. BPX 30-323-15 - Principes généraux pour l'affichage environnemental des produits de grande consommation Partie 15 : méthodologie d'évaluation des impacts environnementaux des produits alimentaires. Référentiel 2012.

Commissariat général au développement durable, service de l'observation et des statistiques. Repères. 2011. Consommation des ménages et environnement.

FNCG, ITERG. 2012. ACéVOL - Analyse de Cycle de Vie pour les Oléagineux. Détermination de l'information environnementale des huiles de colza et de tournesol dites «de référence ». Rapport 2012.

ISO 14044:2006. Management environnemental - Analyse du cycle de vie - Exigences et lignes directrices.

ISO 14040:2006 - Management environnemental - Analyse du cycle de vie - Principes et cadre.

RDC Environnement. 2010. Analyse de cycle de vie d'une bouteille PET. Etude pour Elipso, Valorplast et Eco-Emballages. Rapport 2010, 134 p.

Shen L, Nieuwlaar E, Worrell E, Patel MK. 2011. Life cycle energy and GHG emissions of PET recycling: change-oriented effects. Int. J. Life Cycle Assessment 16 : 522-536.

Cite this article as: Laureen Badey, Natie Lahitte, Francis Flenet, Fabrice Bosque. French environmental communication on sunflower and rapeseed oils based on life cycle assessment. OCL 2013, 20(4) A401. 